\title{
Factors Influencing The Internationalization Of Small And Medium Size Enterprises
}

\author{
Cranmer Rutihinda, Bishop's University, Canada
}

\begin{abstract}
This study explores the factors influencing the internationalization of small and medium enterprises located in the Eastern Townships of Quebec, Canada. Four major factors emerged from the data to explain the internationalization. The four factors include owner manager's international orientation, globalisation of the firm's industry structure, established international networks, and foreign market potential. Successful firms were found to have owner managers with an international orientation and established international networks.
\end{abstract}

Keywords: Internationalization, small and medium size enterprises, Eastern Township

\section{INTRODUCTION}

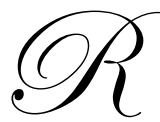
ecognizing the increasing role played by small and medium size enterprises (SME) in economic development and job creation the past two decades have seen a growing interest in the study of international operations of small and medium size enterprises (Ruzzier et al, 2006; Lu and Beamish 2006). However, most of the theories of international business have mainly been focused on the internationalisation of multinational enterprises. It was not until the publication of McDougall and Oviatt's (1994) article titled "Towards a theory of international business studies" that scholars began addressing aspects of international business to explain the internationalisation of small and medium size enterprises or international entrepreneurship. On the other hand, more recent studies (Sharma, 2004, Cerrato, 2007) have suggested that SME internationalisation may be influenced by location and thus calling for more research on the study of internationalization from different national environments. The aim of this paper is to start filling in this gap by exploring the factors influencing the internationalisation of SMEs located in the Eastern Townships of Canada.

\section{LITERATURE REVIEW AND HYPOTHESIS}

Early theories explaining the internationalisation of firms have their roots from economics starting with Hymer's (1976) theory of firm specific advantage which set out to explain what enables firms to carry out international operations. This theory suggested that due to the disadvantages that firms face in foreign markets they can only succeed if they have some superior advantage over local foreign firms. Building on Hymer's work the internalisation theory was used to explain how multinational enterprises are created to overcome market imperfections Rugman (1981) and the Eclectic framework was developed by Dunning (1981) to build upon the existing theory and incorporate the role of location advantage to determine the location of multinational enterprise. Dunning (1993) articulated the major motives for international operations as resource seeking, market seeking and efficiency seeking. However, these theories have mainly been used to explain the internationalisation of large multinational enterprises.

The most popular theory of internationalisation is the Uppsala internationalisation process school that suggests the internationalisation process as a gradual incremental process consisting of a series of stages of increasing involvement in international operations as the company gains international experience (Welch and Loustarien, 1993, 156). This school looks at internationalisation as a learning process where as the firm gains international experience it reduces the risks of operating in foreign environment and can safely increase its resource commitment. However, with the emergence of the born-global firms that emerged with advent of increasing globalisation, the Uppsala internationalisation theory has lost it explanatory power. The recent process of 
globalization driven by the development of information technology, falling trade barriers leading to an increasingly interconnected and interrelated world has rapidly reduced the psychic and geographic distance between countries which undermines the key promises of the Uppsala internationalisation school.

A complement to the internationalisation theory is the network approach (Johanson and Mattson, 1998) that uses the social exchange theory to explain the internationalisation process of firms. By building relationships with other firms in the industry such as suppliers, competitors and customers the firm is able to gain access to assets that overcome the firm's resource constraints. These relationships are therefore considered as market assets that compliment to the firms lack of international knowledge that was earlier developed by the Uppsala school. However, the network approach has been criticised for its lack of incorporating strategic aspects of internationalisation (Rutihinda, 1996).

A promising theory of internationalisation is the Resource-based Internationalisation frame-work (Rutihinda, 1996; Ahokangas, 1998) that builds on the resource-based view of the firm to incorporate strategic management aspects to the internationalisation processes. Building upon the resource-based internationalisation process this study uses the framework illustrated in Figure 1 to explain the internationalisation of SMEs from the Eastern Townships.

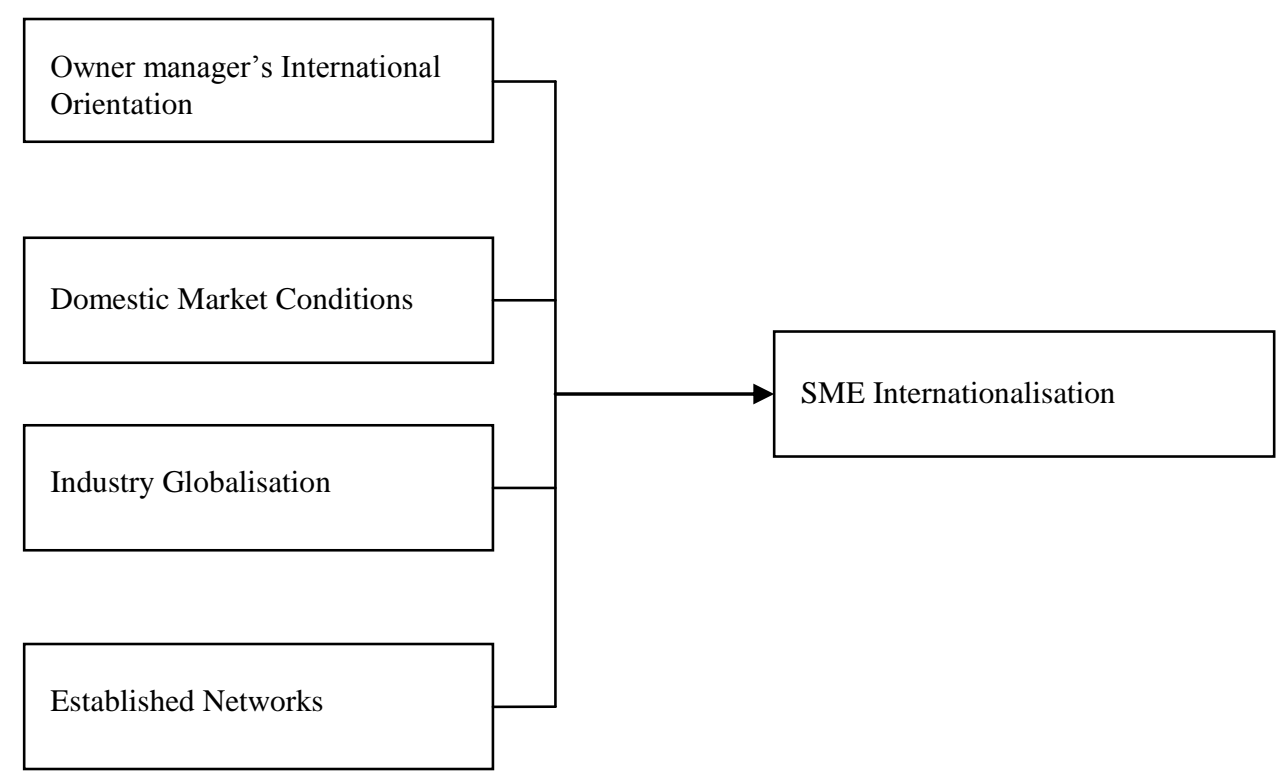

Figure 1: Drivers of SME Internationalisation

The main distinction of small and medium size enterprises is the central role played by he owner manager in making strategic decisions. Unlike large firms that have a large pool of professionals employed to address specialised tasks, small and medium size enterprises are highly dependant on the capabilities of their owner managers. A great deal of the entrepreneurship and small business literature have identified the crucial role played by the owner manager is determining the strategic direction of the business. Management's limitations such as risk aversion or limited knowledge about foreign opportunities can limit the firm's ability to pursue international operations. The initiative to proactively pursue international business opportunities will highly depend on the SMEs owner manager's international vision and exposure to international market opportunities. A Manager's positive perception of foreign markets is likely to commit more resources towards activities with the aim of stimulating growth into international markets.

H1: SMEs with owner managers with an international orientation are more likely to proactively undertake international operations and succeed. 
The domestic environment has been considered in the international marketing literature as providing an environment that would trigger companies to pursue international opportunities. When the domestic market is saturated or when competition is too intensive firms are likely to see growth by searching for opportunities outside their home market. As the domestic competition intensifies companies are driven to become more innovative and efficient which raises their capacity to compete. Conducive domestic market conditions such as well developed supporting institutions including export promotion agencies and other government incentives (access to low interest loans) can trigger local SMEs to search for market opportunities.

H2: SMEs facing high level of domestic competition are more likely to proactively engage in international operations and succeed.

Global industry structure refers to the extent to which a firm's industry has been more global players in the market. Porter (1990) distinguishes global industries as those industries in where competition takes place among firms located in different countries. Small and medium size firms in global industries find themselves facing competition from foreign firms that operate in their local markets. This interaction of local firms with global players is likely to trigger local SMEs to seek opportunities in foreign markets within the same industry.

H3: SMEs operating in globalised industries are more likely to proactively engage in international operations and succeed.

The Network theory suggests that a firm's internationalisation is influenced by its position and relationships in the industrial network. A firm's relationships with other firms in the market place can contribute to its internationalisation process. As the firm takes advantage of its established relationships in the industrial network the SME may be able to overcome its resource constraints by using its partner's resources. Established international networks are likely to encourage small and medium size firms to pursue international operations.

H4: Firms that have more established international contacts are more likely to succeed in international markets.

\section{METHODOLOGY}

Data was collected through a survey of exporting small and medium size firms located in the Eastern Townships. The study sample was drawn from a list of registered exporters from the Eastern Townships. From this list, only exporting firms with less than 500 employees were included in the contact list. A contact list of 275 SME exporters located in the Eastern Townships was identified where all 275 SMEs were first contacted by phone and later a questionnaire was sent to all respondent who accepted to take part in this survey. Out of that list, ninety respondents refused to participate in this study for various reasons leaving a list of 188 firms from which constant contacts were made to encourage their response. Finally, after all the means to solicit responses were exhausted, only 71 positively responded to the questionnaire. However, after scrutiny of the responses only 64 cases were found eligible for further analysis which represents a response rate of 23 percent of the original targeted population. Table1 below provides the characteristics of the firms in the sample. Thirty eight percent of the firms in the sample were in the manufacturing of industrial goods while 25 percent were in the consumer durable industries and the rest were in the manufacturing of non-durables including health care and pharmaceuticals.

Table 1: Respondent by Industry

\begin{tabular}{|l|c|c|}
\hline \multicolumn{1}{|c|}{ Industry } & N & Percent \\
\hline Manufacturing consumer non-durables & 5 & 8 \\
Manufacturing consumer durables & 16 & 25 \\
Manufacturing Industrial goods & 24 & 38 \\
Health care and Pharmaceutical & 2 & 3 \\
Telecommunications and IT & 12 & 19 \\
Professional Services & 4 & 6 \\
Other & 1 & 2 \\
\hline Total & $\mathbf{6 4}$ & $\mathbf{1 0 0}$ \\
\hline
\end{tabular}


Examining the sample by size of respondents in terms of employees and sales turnover, we find that most of firms in the sample have more activities outside the Eastern Township with most of their sales taking place in the USA and other parts of Canada. This reflects the Eastern Townships' location advantage of being closely located to the USA borders along with the long historical ties between communities of both sides of the border.

Table 2: Firm Size by Location in Number of Employee and Sales Turnover

\begin{tabular}{|l|c|c|c|c|}
\hline & Eastern Townships & Other Canada & USA & Other Countries \\
\hline No of Employee & & & & \\
Under 20 employees & 34 & 59 & 60 & 11 \\
21 to 50 employees & 31 & 7 & 7 & 2 \\
$\mathbf{5 1 - 5 0 0}$ employees & 30 & 3 & 61 & 0 \\
\hline Sales in Canadian Dollars & & & & \\
Less than \$1million & 27 & 20 & 20 & 6 \\
\$1 to 10 million & 33 & 37 & 30 & 3 \\
More than 10 million & 5 & 6 & 13 & \\
\hline
\end{tabular}

The survey's main source of data was through a structured interview. Measures used in this study have been drawn from similar empirical studies on SME internationalisation. Since the Eastern Townships are bilingual, to ensure adequate cooperation and accuracy of the data the questionnaires were first prepared in English then translated into French and from French into English again using independent translators. A bilingual approach was used to contact the respondents, respondents who preferred English were provided with an English questionnaire and those that preferred French received a French questionnaire. To facilitate the interpretation of the survey findings an in-depth case study from the successful exporting SME was used.

\section{ANALYSIS}

Measures used to explore the reasons that prompted SMEs to export are as shown in Table 3., From the results of the survey we find the major reasons that drove exports from Esterie to include International vision of managers, large proportion of potential foreign customers, identification of international opportunity, personal contacts, and to improve domestic sales.

Table3: Export Driver Variables

\begin{tabular}{|c|c|c|c|}
\hline & Mean & Std. Deviation & $\mathbf{N}$ \\
\hline International vision of managers & 6.79 & 2.812 & 63 \\
\hline Large proportion of potential foreign customers & 6.56 & 2.717 & 63 \\
\hline International competitive nature of Industry & 6.33 & 2.700 & 63 \\
\hline Identification of international opportunity & 6.06 & 2.633 & 63 \\
\hline Personal knowledge $\&$ contacts with int. customers & 6.06 & 2.602 & 63 \\
\hline Improve domestic sales & 6.03 & 3.005 & 63 \\
\hline Desire to be an international market leader & 5.90 & 3.151 & 63 \\
\hline International experience of managers & 5.67 & 2.857 & 63 \\
\hline Small domestic market & 5.63 & 2.824 & 63 \\
\hline International sales needed for economies of scale & 4.78 & 2.937 & 63 \\
\hline Need to respond to competitors initiatives & 4.37 & 2.864 & 63 \\
\hline Pressure from firm's customers & 4.37 & 2.858 & 63 \\
\hline Advances in IT have reduced international barriers & 4.16 & 2.963 & 63 \\
\hline Increased homogeneity of international markets & 4.08 & 2.726 & 63 \\
\hline Desire to capitalize on proprietary technology & 3.98 & 2.948 & 63 \\
\hline Avoidance of intense domestic competition & 3.95 & 2.581 & 63 \\
\hline High $R \& D$ costs necessitated international sales & 3.84 & 2.841 & 63 \\
\hline Influence from firm's business partners & 3.62 & 2.802 & 63 \\
\hline Short product life cycles necessitated int. sales & 3.38 & 2.921 & 63 \\
\hline Advice from government agencies & 3.10 & 2.613 & 63 \\
\hline Need to obtain foreign financing & 2.59 & 2.325 & 63 \\
\hline
\end{tabular}


Since export drivers are complex phenomena, to identify the underlying constructs of export drivers, the variables listed in Table 3 were subject to factor analysis. A correlation matrix of all the above variables was computed and KMO measure of sampling adequacy was used to examine the correlation matrix. The KMO measure of sampling adequacy was 0.73 suggesting that we can comfortably proceed with the factor analysis. The variables were then extracted using principal component analysis. As seen in Table 4 four factors emerged with eigen values greater than 1 . These four factors explained 67 percent of the total variance.

Table 4: Explained Variance

\begin{tabular}{|c|c|c|c|}
\hline & Initial Eigenvalues & $\%$ of Variance & Cumulative \% \\
\hline International Vision of Managers & 34.805 & 34.805 & 34.805 \\
\hline Large Proportion of Potential Foreign Customers & 11.156 & 11.156 & 45.961 \\
\hline Int. \& Comp. Nature of Industry & 8.702 & 8.702 & 54.663 \\
\hline Identification of International opportunity & 6.541 & 6.541 & 61.204 \\
\hline International experience of Managers & 5.550 & 5.550 & 66.754 \\
\hline Desire to be an International Market Leader & 4.619 & & \\
\hline Personal Knowledge \& Contacts with Int. Customers & 3.793 & & \\
\hline International Sales Needed for Economies of Scale & 3.733 & & \\
\hline Desire to capitalize on proprietary tech. & 3.345 & & \\
\hline Need to Respond to Competitors Initiatives & 3.000 & & \\
\hline Improve Domestic Sales & 2.566 & & \\
\hline Small Domestic Market & 2.048 & & \\
\hline Advances in IT have have reduced Int. Bus. Barriers & 2.005 & & \\
\hline High R\&D Costs necessitated International Sales & 1.814 & & \\
\hline Increased Homogeneity of Int. Markets & 1.552 & & \\
\hline Pressure from Firm's Customers & 1.425 & & \\
\hline Influence from Firm's Business Partners & .932 & & \\
\hline Short Product Life Cycles Necessitated Int. Sales & .889 & & \\
\hline Advice from Government Agencies & .661 & & \\
\hline Avoidance of intense domestic competition & .523 & & \\
\hline Need to Obtain Foreign Financing & .340 & & \\
\hline
\end{tabular}

Table 5 below shows the results of the rotated four factor solution. From the factor loadings we can interpret the factors as Owner manager's international orientation, SMEs industry globalisation, domestic industry condition, SMEs established networks, and foreign market potential, as the main drivers of SME internationalisation. To determine the reliability of the factors loadings the items in each factor were tested using Cronbach alpha. Results show all the four factors with Cronbach alpha greater than 0.60 . 
Table 5: Export Drivers

\begin{tabular}{|c|c|c|c|c|c|}
\hline & $\begin{array}{c}\text { International } \\
\text { Orientation }\end{array}$ & $\begin{array}{c}\text { Industry } \\
\text { Globalization }\end{array}$ & $\begin{array}{l}\text { Domestic } \\
\text { Industry } \\
\text { Condition }\end{array}$ & $\begin{array}{c}\text { International } \\
\text { Networks }\end{array}$ & $\begin{array}{c}\text { Foreign } \\
\text { Market } \\
\text { Potential }\end{array}$ \\
\hline $\begin{array}{l}\text { International experience of Managers } \\
\text { International Vision of Managers } \\
\text { Desire to be an International Market Leader } \\
\text { Int. \& Comp. Nature of Industry } \\
\text { High R\&D Costs necessitated International Sales } \\
\text { Increased Homogeneity of Int. Markets } \\
\text { Need to Respond to Competitors Initiatives } \\
\text { Advances in IT have reduced Int. Bus. Barriers } \\
\text { International Sales Needed for Economies of Scale } \\
\text { Desire to capitalize on proprietary tech. } \\
\text { Avoidance of intense domestic competition } \\
\text { Improve Domestic Sales } \\
\text { Short Product Life Cycles Necessitated Int. Sales } \\
\text { Need to Obtain Foreign Financing } \\
\text { Advice from Government Agencies } \\
\text { Personal Knowledge \& Contacts with Int. } \\
\text { Customers } \\
\text { Identification of International opportunity } \\
\text { Pressure from Firm's Customers } \\
\text { Influence from Firm's Business Partners } \\
\text { Large Proportion of Potential Foreign Customers } \\
\text { Small Domestic Market }\end{array}$ & $\begin{array}{l}.823 \\
.818 \\
.776 \\
.703\end{array}$ & $\begin{array}{r}.811 \\
.789 \\
.539 \\
.535 \\
.527 \\
.441 \\
\end{array}$ & $\begin{array}{l}.770 \\
.766 \\
.713 \\
.582\end{array}$ & $\begin{array}{l}.820 \\
.737 \\
.655\end{array}$ & $\begin{array}{l}.703 \\
.702\end{array}$ \\
\hline
\end{tabular}

Using the above same procedure, measures for SME performance were subject to factor analysis and the results are as seen in Tables 6 and Table 7. Two factors emerged with eigen values greater than one. These factors explained 80 percent of the total variance.

Table 6: Firm Performance Measures

\begin{tabular}{|l|c|c|c|c|}
\hline & Communalities & Eigen Values & \% of Variance & Cumulative \% \\
\hline Sales Level & .887 & 4.163 & 59.471 & 59.471 \\
Sales Growth Rate & .879 & 1.419 & 20.274 & 79.745 \\
Cash Flow & .515 & & & \\
Gross Profit & .847 & & & \\
Net Profit from Operations & .823 & & \\
Return on Investment & .841 & & & \\
Ability to Fund Business Growth from Profits & .790 & & \\
\hline
\end{tabular}

Based on the composition of variables in each factor we can confidently suggest that the first factor measures the firm's profitability while the second factor measures the firm's sales performance.

Table 7: Performance Measures

\begin{tabular}{|l|c|c|}
\hline & Profitability & Sales \\
\hline Ability to Fund Business Growth from Profits & $\mathbf{. 8 7 6}$ & .152 \\
Return on Investment & $\mathbf{. 8 6 9}$ & .293 \\
Gross Profit & $\mathbf{. 8 5 1}$ & .351 \\
Net Profit from Operations & $\mathbf{. 8 3 2}$ & .360 \\
Cash Flow & $\mathbf{. 7 0 5}$ & -.136 \\
Level of Sales & .159 & $\mathbf{. 9 2 8}$ \\
Sales Growth Rate & .157 & $\mathbf{. 9 2 4}$ \\
Cronbach Alpha & .905 & .902 \\
\hline
\end{tabular}


In order to determine the relationships between internationalisation drivers and firms performance, the measures were subject to cluster analysis. Results of the two cluster solution are shown in Table 8.

Table 8: Export Drivers and Firm Performance

\begin{tabular}{|l|c|c|c|}
\hline & Successful & Unsuccessful & Significance \\
\hline International Orientation & .53193 & -.71725 & .000 \\
Industry globalization & .11495 & -.10445 & .394 \\
Domestic Competition & .24388 & -.31021 & .031 \\
International Networks & .17645 & -.25718 & .095 \\
Foreign Market Potential & -.15615 & .22754 & .140 \\
Sales Performance & .51028 & -.71153 & .000 \\
Number of Cases & 36 & 26 & \\
\hline
\end{tabular}

The first group of clusters consists of 36 firms that can be described as the successful firms with a favourable sales growth. Firms in this cluster were driven by managers with a very strong international orientation. These firms were also driven to internationalise by their already established business networks. Domestic industry structure also played an important role in successful firms. However, results show no significant relationships between the firms' industry globalisation and firm performance. There is also no significant relationship between SME's foreign market potential and performance. These results support

\section{THE CASE A SUCCESSFUL SME IN THE BEVERAGE INDUSTRY}

The above SME export drivers can be illustrated by the internationalization process of a small familyowned SME located on the slopes of in the Eastern Township exporting a high-end beverage. This company is currently involved in 20 different countries among of which include the U.S, France, Italy, Japan, Hong Kong, China and Korea. Activities outside Canada are mainly managed through foreign distributor who deals with the upper-end market segment in this respective industry. The product is also sold by duty free agents in international airports.

The company operated for only two years since its inception in Canada before it decided to export. One of the owners had previously worked in several companies known for selling branded products in international markets. According to the owners, the domestic market was still growing with untapped growth potential but the entrepreneurial mindset of the company owners triggered them to realise the value of gaining a grip in a foreign market as early as possible. As described by the owner the mission of the company is to be the world leader in this special market niche.

According to the owner manager the product is at the beginning of its life cycle, but the pace of growth is fast as markets are growing exponentially mainly due to globalisation. The global demand of the product enabled the owners to quickly take advantage of the demand gap and expand their market base globally starting with the duty free market outlets at airports.

Although this product is fairly new in the global markets, in the home market other competitors have started to imitate the product but with relatively poor quality. This domestic competition has emerged as a result of the company's rapid growth in Quebec where the product has become known and is in high demand. The company's biggest challenge (according to the owner) is to meet the growing demand. Since this product is differentiated by its unique product production process that is tied to the Easter Township location the product meets very little competition in international markets. Even for producers in the same location the products unique taste and the now strong brand name attached to this product makes it hard for competitors to copy.

Most of the value chain activities are carried out within the Eastern townships and its exports take place through a high end specialised distributor. As the pioneer of this product this company was able to easily gain market access and was also able to lock-up the best distributor to partner with in foreign markets. The owner met the distributor in an international trade fair where both parties came to developed contacts and relationships. 
The success of this SME can be explained by its management's entrepreneurial and international orientation, its favourable domestic market conditions, and established networks. Currently this SME is the leader in its product market. In Quebec the company has done "well above expectations". Largely this can be attributed to good relationship that has been established with the local distributors. Having a newly created SME become the market leader in this industry is amazing. Given that the industry in Canada is over 4.2 billion (Statcan 2006), the threat of having one of the main industry players make the transition into this product is ever present. However it is not surprising that there has been success in this industry, given the fact that the Canadian industry had the 11th highest growth rate among 215 industry groups between 1997 and 2001. This growth in this industry was mainly driven by local demand, where as the foreign demand of related product category was $88 \%$ of total industry exports (Statcan 2006).

\section{CONCLUSION}

Using factor analysis this study has explored the factors influencing the internationalisation of small and medium size firms located in the Canadian Eastern Townships (Esterie). Four major factors have emerged from the data to explain the internationalisation of these SMEs. These factors include SMEs owner manager's international orientation, globalisation of SME's industry, SME's established international networks, and foreign market potential. Successful firms were also found to have owner managers with an international orientation with established international contacts. This study was limited by its relatively small sample size. Future studies can replicate this study by using larger samples. For policy makers this study has identified the role of a conducive domestic environment and an international orientation as important drivers of SMEs international success. Exposing SMEs to more international market opportunities can stimulate SME export growth. For SME managers this study suggests a more proactive approach to internationalisation that guarantee successful international operations through establishing international networks.

\section{AUTHOR INFORMATION}

Dr. Cranmer Rutihinda is an Associate Professor in the Department of Business at Bishop's University. His main research interests include International Entrepreneurship and International Marketing.

\section{REFERENCES}

1. Ahokangas, P. (1998) Internationalisation and reosuces: an analysis of processes in Nordic SMS, doctroral dissertation, Universitas Wasaensis, Vaasa

2. Barnes, B. R., R. Chakrabarti and D. Palihawadana (2006) Investigating the export marketing activity of SMEs operating in international healthcare markets, Journal of Medical Marketing Vol. 6, 3 209-221

3. Bell, J., McNaughton, R., Young, S and Crick, D. (2003) Towards and Integrative Model of Small Firm Internationalisation Journal of International Entrepreneurship 1, 33-362

4. Carter, N. M., T. M. Stearns, P. D. Reynolds, and B. A. Miller (1994) New Venture Strategies: Theory Development with an Empirical Base. Strategic Management Journal, Vol. 15, 21-41.

5. Cerrato, D. and M. Piva (2007) The Internationalisation of Small and Medium-Sized Enterprises: The Effects of Family Management, Human Capital and Foreign Ownership. Working Paper DICE October Universita Cattolica

6. Dunning J. H. (1981) International Production and the Multinational Enterprise, London; George Allen \& Unwin

7. $\quad$ Dunning J. H. (1993) Multinational Enterprise in the Global Economy, Wokingham

8. Evangelista F. (2005) Qualitative Insights into the International New Venture Creation Process. Journal of International Entrepreneurship 3, 179-198

9. Hymer, S. H. (1976) The International Operations of National Firms: A study of Direct Foreign Investment. Cambridge MIT Press

10. Ibeh K. I. N (2003) Towards a Contingency Framework of Export Entrepreneurship: Conceptualisations and Empirical Evidence, Small Business Economics 20: 49-68 
11. Jeffrey Johnson (2004) Factors influencing early internationalization of High technology start-ups: in US and UK evidence, Journal of International Entrepreneurship.

12. Johnson J. E. (2004) Factors Influencing the Early Internationalization of High Technology Start-ups: US and UK Evidence. Journal of International Entrepreneurship 2, 139-154

13. Lu J. W. and P. W. Beamish (2006) SME Internationalization and Performance: Growth vs profitability. Journal of International Entrepreneurship Vol. 4: 27-48

14. MacMillan, I. C. and D. L. Day (1987) Corporate ventures into industrial markets: Dynamics of aggressive entry, Journal of Business Venturing, 2(1), pp. 29-40.

15. Mickiewicz, T. and Aidis, Ruta (2006) Entrepreneurs, Expectations and Business Expansion: Lessons from Lithuania Europe-Asia Studies Vol. 58, No. 6

16. Oviatt, B. M. and McDougall, P. P. (1994) Toward a theory of international business studies, Journal of International Business Studies, 25 (1): 45-64

17. Penrose, E. T. (1959) A theory of the growth of the firm. New York: Wiley.

18. Peteraff, M. (1993) The Cornerstones of Competitive Advantage: A resource-based view. Strategic Management Journal, 14, 179-192.

19. Pfeffer, J. \& G. Salancik (1978) The External Control of Organizations. New York Publishers.

20. Porter, M. E. (1980) Competitive Strategy. New York. Free Press.

21. Porter, M. E. (1990) The Competitive Advantage of Nations. New York. Free Press.

22. Rugman, Alan (1981) Inside the Multinational; The Economics of Internal Markets. Columbia University Press, New York

23. Rutihinda, C (1996) Resource-based Internationalisation. PhD Thesis, Stockholm University

24. Rutihinda, C. (2005) Strategy and Performance of Small and Medium Size Enterprises in Tanzania, Applied Business Research Conference Proceedings, Florida, USA

25. Sharma, P. (2004) An Overview of the Field of Family Business Studies: Current Status and Directions for Future, Family Business Review, 17, (1), 1-36

26. Turnbull, P. W., and J. P. Valla, (eds.), 1986, Strategies for International Industrial Marketing. London: Croom-Helm.

27. Johanson, J. and L-G Mattson, (1993) Internationalization in industrial systems-a network approach, strategies in global competition, in Buckley, P. J. and Ghauri, P. N. (eds) The Internationalization of the Firm a Reader, Academic Press, London pp. 303-22 
NOTES 